\title{
PENERAPAN PENDEKATAN BERBASIS GENRE DALAM PENGAJARAN MENULIS TEKS PADA SISWA KELAS X SMA SWASTA MULIA
}

\author{
Nurvita Sari Musdiani Silalahi ${ }^{1}$, Masitowarni Siregar ${ }^{2}$, Silvy P. \\ Maharani $^{3}$, Afanin Nabila ${ }^{4}$ \\ Pendidikan Bahasa Inggris, Universitas Negeri Medan, Indonesia \\ nurvitasarimusdianisilalahi@gmail.com
}

\begin{abstract}
Abstrak. Keterampilan mengajar menulis menggunakan pendekatan berbasis genre melibatkan lima tahap, yaitu: 1) Membangun konteks, 2) Membuat model dan mendekonstruksi teks, 3) Konstruksi bersama dari teks, 4) Konstruksi teks independen, dan 5) Menghubungkan teks terkait. Adapun masalah yang dihadapi guru, yaitu waktu mengajar yang kurang memadai, guru tidak bisa memantau semua siswa, siswa tidak memiliki banyak kosakata dan siswa kurang dalam pengucapan. Tujuan dari penelitian ini adalah untuk menggambarkan penerapan Pendekatan Berbasis Genre dalam keterampilan mengajar menulis di Swasta Mulia Medan. Tujuan dari penelitian ini adalah untuk mengetahui bagaimana penerapan keterampilan pengajaran menulis di Swasta Mulia Medan dengan menggunakan Pendekatan Berbasis Genre.Penelitian ini menggunakan penelitian kualitatif deskriptif sebagai desain penelitian. Tujuan penelitian deskriptif adalah untuk membuat deskripsi tentang fenomena faktual dalam pengajaran untuk mendapatkan informasi. Peneliti menjelaskan implementasi Pendekatan Berbasis Genre dalam mengajar keterampilan membaca. Metode pengumpulan data adalah observasi, wawancara dan dokumentasi. Data dianalisis dengan reduksi data, menampilkan data, menarik kesimpulan. Penelitian ini peneliti menggunakan metode triangulasi yaitu observasi, dokumentasi, dan wawancara.
\end{abstract}

Kata Kunci: Pendekatan Berbasis Genre, Menulis, Teks Deskripsi 
Nurvita Sari Musdiani Silalahi ${ }^{1}$, Silvy P. Maharani ${ }^{2}$, Afanin Nabila ${ }^{3}$

Penerapan Pendekatan Berbasis Genre Dalam Pengajaran Menulis Teks Pada

Siswa Kelas X SMA Swasta Mulia

\section{PENDAHULUAN}

Bahasa Inggris adalah salah satu bahasa yang digunakan sebagai sarana komunikasi dari bahasa bahasa yang ada di seluruh dunia ini. Bahasa Inggris adalah bahasa internasional dan digunakan oleh banyak orang di seluruh dunia. Menguasai Bahasa Inggris sangat penting dalam masyarakat kita di dunia, karena dengan belajar Bahasa Inggris, siswa dapat memiliki kesempatan untuk meraih masa depan yang cerah. Saat ini, perusahaan tidak hanya membutuhkan kemampuan di bidangnya, tetapi juga orang-orang yang dapat memiliki komunikasi bahasa Inggris yang baik.

\section{Belajar bahasa Inggris sangat} penting bagi kebanyakan orang, terutama dalam pendidikan. Ini akan membantu pelajar untuk mengembangkan bahasa Inggris mereka dengan lebih baik dan lebih mudah. Di Indonesia, bahasa Inggris digunakan dalam pendidikan mulai dari sekolah menengah pertama hingga perguruan tinggi. Penting untuk diingat bahwa tidak ada satu variasi bahasa Inggris tertentu yang secara intrinsik lebih baik daripada guru bahasa Inggris lainnya dan dapat berasal dari latar belakang bahasa apa pun. Karena alasan itu, bahasa Indonesia menerapkannya sebagai bahasa asing pertama yang harus dipelajari oleh siswa.

Ada empat keterampilan dalam pembelajaran bahasa Inggris, mereka membaca, menulis, mendengarkan, dan berbicara. Menulis adalah keterampilan yang paling sulit di antara keempat untuk dicapai atau dikuasai siswa Indonesia. Oleh karena itu, cara atau metode yang paling efektif sangat dibutuhkan untuk menyelesaikan masalah atau kesulitan tersebut. Akibatnya, sebuah studi perlu dilakukan untuk meningkatkan prestasi siswa dalam menulis. Penelitian ini bertujuan menerapkan metode untuk meningkatkan prestasi siswa dalam menulis teks. Secara khusus, metode yang dipilih adalah yang didasarkan pada genre atau pendekatan berbasis teks.

Agar dapat melakukan kegiatan belajar mengajar berbasis genre di kelas dengan baik, guru harus memahami penerapan Pendekatan Berbasis Genre. Memahami berarti bahwa para guru memiliki pengetahuan tentang Pendekatan Berbasis Genre dan implementasinya, mereka memahami tentang penerapan Pendekatan Berbasis Genre dan mereka memiliki pendapat terhadap implementasi Pendekatan Berbasis Genre.

Dalam menerapkan GenreBased Approach dalam kurikulum bahasa Inggris, ada lima langkah yang harus diikuti: membangun pengetahuan lapangan, pemodelan, konstruksi bersama, konstruksi mandiri, dan menghubungkan teks terkait. Untuk dapat melaksanakan kegiatan belajar mengajar berbasis genre di kelas dengan baik, guru harus memahami penerapan Genre-Based Approach. Memahami artinya guru memiliki pengetahuan tentang GenreBased Approach dan implementasinya, mereka memahami tentang penerapan Genre-Based Approach dan memiliki pendapat terhadap penerapan GenreBased Approach.

$\begin{array}{ccc} & \text { Penelitian ini dilakukan di } \\ \text { SMA } & \text { Swasta Mulia. Peneliti }\end{array}$ mengamati dan mewawancarai guru bahasa Inggris dan juga siswa. Siswa 


\section{Nurvita Sari Musdiani Silalahi ${ }^{1}$, Silvy P. Maharani ${ }^{2}$, Afanin Nabila ${ }^{3}$ \\ Penerapan Pendekatan Berbasis Genre Dalam Pengajaran Menulis Teks Pada Siswa Kelas X SMA Swasta Mulia}

kelas X sebagai objek penelitian ini. Hal ini dikarenakan mereka masih siswa baru yang belajar keterampilan menulis dengan metode Genre-Based Approach di SMA, dan mereka memiliki persiapan yang baik dalam memahami materi. Ketika peneliti bertanya kepada mereka tentang pelajaran menulis, mereka mengatakan bahwa mereka tidak bosan untuk belajar, karena guru bahasa Inggris mengajar mereka menggunakan kegiatan yang dapat menghindarkan mereka dari rasa bosan. Jadi, siswa tidak merasa bosan. Namun dalam wawancara dengan guru bahasa Inggris, penerapan Genre-Based Approach masih belum efektif karena terdapat beberapa kesulitan dalam proses belajar mengajar terutama dalam menulis teks misalnya dalam prestasi belajar siswa. Walaupun siswa tidak bosan, namun menurut mereka belajar bahasa Inggris khususnya menulis teks masih sulit. Tidak hanya itu, guru juga masih belum mengetahui cara mengajar menulis teks dengan mengikuti langkah-langkah GnenreBased Approach. Pendekatan ini memiliki beberapa kesamaan dengan Pendekatan Ilmiah. Jadi, terkadang guru tidak dapat memahami perbedaan antara Pendekatan Berbasis Genre dan Pendekatan Ilmiah. Untuk itu peneliti melakukan penelitian yang berjudul Penerapan Pendekatan Berbasis Genre dalam Pengajaran Menulis Teks Kelas $X$ di SMA Yayasan Pendidikan Mulia.

\section{LANDASAN TEORI}

\section{Menulis}

Menulis adalah bentuk komunikasi yang penting dalam kehidupan sehari-hari. Orang-orang mengomunikasikan ide, makna, pesan, perasaan, emosi, dan cinta mereka tidak hanya melalui berbicara tetapi juga secara tertulis.

Menulis adalah pekerjaan mental untuk menciptakan ide-ide, berpikir tentang bagaimana mengekspresikannya, dan mengaturnya dalam pernyataan dan paragraf yang akan lebih jelas bagi pembaca (Nunan, 2003: 88). Proses menciptakan ide-ide terjadi pada tahap pra-penulisan. Lerdpreedakorn $\mathrm{N}$ (2009) juga menyatakan bahwa menulis mungkin salah satu yang paling penting.

Menulis membantu siswa untuk memikirkan ide dengan cermat dan logis. Menulis tidak sesederhana yang dibayangkan karena itu adalah proses menghubungkan kata ke dalam kalimat dan paragraf. Organisasi ide sangat penting. Ketika seseorang berbicara tentang menulis, ia sering berpikir tentang unsur-unsur seperti pilihan kata, tata bahasa, dan kosa kata.

\section{Karakteristik Genre}

\section{Definisi Genre}

Genre cukup mudah digunakan untuk merujuk pada kategori wacana khas dalam jenis apa pun, lisan atau tulisan, dengan atau tanpa aspirasi sastra. Secara etimologis, kata 'genre' berasal dari bahasa Perancis yang berarti 'bentuk' atau 'jenis'. Kemudian, awalnya, kata 'genre' yang juga digunakan dalam ilmu Biologi berarti 'genus' mengacu pada klasifikasi flora dan fauna (Stokes, 2006; Himawan, 2007). Ini berarti bahwa konsep awal genre adalah untuk mengklasifikasikan spesies ke dalam kelas tertentu karena karakteristiknya yang serupa (Dirgeyasa, 2015). Sebagian besar genre menggunakan konvensi yang 


\section{Nurvita Sari Musdiani Silalahi ${ }^{1}$, Silvy P. Maharani ${ }^{2}$, Afanin Nabila ${ }^{3}$ \\ Penerapan Pendekatan Berbasis Genre Dalam Pengajaran Menulis Teks Pada \\ Siswa Kelas X SMA Swasta Mulia}

berkaitan dengan tujuan komunikatif, surat pribadi dimulai dengan pertanyaan ramah dalam suasana hati yang ramah karena tujuannya adalah untuk menjaga hubungan yang baik, dan esai argumen menekankan tesisnya karena bertujuan membuat argumen. Brown (2001: 99) menyatakan bahwa, "genre telah menarik perhatian pada cara-cara di mana teks dibangun dan telah mengidentifikasi karakteristik dari berbagai jenis teks." Ini berarti bahwa setiap genre memiliki karakteristik dan tujuan sosial masing-masing.

\section{Sifat Pendekatan Berbasis Genre}

\section{a. Definisi Pendekatan Berbasis Genre}

Pendekatan berbasis Genre, juga dikenal sebagai pendekatan berbasis teks, melihat kompetensi komunikatif yang melibatkan penguasaan berbagai jenis teks. Teks di sini digunakan dalam arti khusus untuk merujuk pada urutan bahasa terstruktur yang digunakan dengan cara tertentu. Lebih lanjut, Fauziati (2009: 209) mengatakan bahwa dalam hal implementasi kelas, pendekatan berbasis genre juga menyerupai pendekatan produk dalam teks model yang dianalisis berdasarkan fitur tata bahasa dan teks. Lebih lanjut, Fauziati (2009: 223) menjelaskan bahwa pendekatan berbasis genre di mana pengajaran dan pembelajaran didasarkan pada hasil analisis genre dan yang berfokus pada pemahaman dan produksi genre teks yang dipilih telah ada bersama kami sejak tahun 1970-an dan pertama kali dipopulerkan. sebagai teknik mengajar.

\section{METODE PENELITIAN}

Penelitian ini akan dilakukan dengan menggunakan penelitian kualitatif deskriptif sebagai desain penelitian. Tujuan dari penelitian deskriptif adalah membuat gambaran tentang fenomena faktual dalam pembelajaran untuk memperoleh informasi. Menurut Heigham dan Croker (2009: 9) penelitian kualitatif merupakan metodologi penelitian yang sangat berguna karena bersifat eksploratif, tujuannya untuk menemukan ide dan wawasan baru, atau bahkan menghasilkan teori baru. Penelitian ini tidak serta merta dilakukan untuk memprediksi apa yang mungkin terjadi di masa depan atau di setting lain, apa yang dipelajari tentang fenomena, partisipan, atau kejadian di setting bisa menjadi tujuan itu sendiri.

Penelitian kualitatif adalah istilah umum. Ini adalah cara untuk mengetahui di mana seorang peneliti mengumpulkan, mengatur, dan menafsirkan informasi yang diperoleh dari manusia menggunakan mata dan telinganya sebagai filter. Ini sering melibatkan wawancara mendalam dan pengamatan manusia dalam pengaturan alam dan sosial. Creswell (2014: 32) mendefinisikan bahwa penelitian kualitatif adalah suatu pendekatan untuk mengeksplorasi dan memahami makna individu atau kelompok yang dianggap sebagai masalah sosial atau manusia. Selain itu, peneliti akan mendeskripsikan Genre-Based Approach yang diterapkan dalam pembelajaran keterampilan menulis pada siswa kelas X SMA Swasta Mulia.

Penelitian ini akan dilakukan dengan mengamati apa yang guru ajarkan kepada siswa dengan 
menggunakan Pendekatan Berbasis Genre. Setelah itu peneliti mendeskripsikan dan menganalisis tentang pengajaran menulis. Kesimpulannya, penelitian ini menggunakan penelitian kualitatif karena datanya adalah berupa penjelasan, deskripsi, dan interpretasi tentang Genre-Based Approach dalam pembelajaran menulis teks pada siswa kelas X SMA Swasta Mulia.

\section{HASIL PEMBAHASAN}

Berdasarkan observasi yang telah dilakukan peneliti selama pembelajaran keterampilan menulis dengan pendekatan Genre-Based Approach ditemukan beberapa temuan. Hasil temuan peneliti mengenai penerapan Genre-Based Approach dalam pembelajaran keterampilan menulis pada siswa kelas X SMA Pendidikan Mulia adalah sebagai berikut:

\section{Penerapan Genre-Based Approach dalam Mengajar Keterampilan Menulis pada Siswa Kelas X SMA Pendidikan Mulia}

Berdasarkan data observasi dan wawancara yang dilakukan oleh peneliti, pembelajaran keterampilan menulis dengan pendekatan GenreBased Approach meliputi lima tahap, yaitu: 1) Membangun konteks, 2) Memodelkan dan mendekonstruksi teks, 3) Konstruksi gabungan dari teks. teks, 4) Konstruksi teks independen, dan 5) Menghubungkan teks terkait. Pembelajaran bahasa Inggris dengan Genre-Based Approach dalam pembelajaran keterampilan menulis dilakukan di kelas X IPS-1 SMA Pendidikan Mulia. Kelas IPS1 kesepuluh terletak di kelas $2^{\text {nd }}$ Lantai, terdiri 15 siswa, 7 perempuan dan 8 laki-laki. Guru Bahasa Inggris bernama Tri Anggraini, S.Pd yang menangani pembelajaran Bahasa Inggris untuk siswa kelas XI. Pembelajaran bahasa Inggris dengan Genre-Based Approach dalam keterampilan menulis membutuhkan waktu yang lama agar dapat dipahami dengan baik. Hal tersebut dibuktikan dengan pernyataan dari wawancara dengan guru:

"Saat saya mengajar dan menjelaskan materi kepada siswa saya membutuhkan banyak waktu, karena jika siswa kurang paham tentang materi maka saya harus menjelaskan lagi. Contoh, ketika saya mengajar teks deskriptif, saya menjelaskan tentang materi teks deskriptif sampai siswa memahami apa arti teks tersebut, apa tujuannya."

Ada beberapa kegiatan kelas yang dilakukan dalam pembelajaran bahasa Inggris khususnya dalam pembelajaran keterampilan menulis di SMA Pendidikan Mulia. Aktivitas dijelaskan di setiap tahap. Sebelum memulai pelajaran, guru membuka dengan mengucapkan "Assalamualaikum" kepada siswa. Setelah itu, guru memeriksa kehadiran siswa yang tidak hadir. Kemudian guru memulai pembelajaran dengan beberapa kegiatan. Guru yang tangguh berusaha membuat siswa menarik dan menikmati di dalam kelas.

Proses belajar mengajar terdiri dari lima tahap, yaitu: 1) Membangun konteks, 2) Pemodelan dan dekonstruksi teks, 3) 
Konstruksi teks bersama, 4) Konstruksi independen teks, dan 5) Menghubungkan teks terkait. Guru mengajar siswa dengan pendekatan Genre-Based Approach agar memiliki kemampuan yang baik dalam pembelajaran bahasa Inggris terutama dalam mengajar keterampilan menulis. Peneliti akan menjelaskan lima langkah sebagai berikut:

\section{Membangun Konteks}

Kegiatan pada tahap ini peneliti melakukan observasi di kelas pada saat guru memberikan pembelajaran. Guru memulai pembelajaran dengan memberikan peringatan kepada siswa, guru menjelaskan teks deskriptif dan mendiskusikan tentang "Mendeskripsikan Orang". Pada tahap ini sebelum guru memulai diskusi guru memberikan beberapa pertanyaan yang berhubungan dengan materi. Materi hari itu adalah teks deskriptif. Kemudian, siswa mengutarakan pendapatnya. Setelah itu guru menjelaskan apa yang dimaksud dengan teks deskriptif, apa saja struktur generiknya, fungsi sosial dan ciri bahasanya. Terbukti guru meminta siswa untuk menebak topik apa:

"Topik apa yang akan dipelajari?" Siswa menjawab "Kita akan belajar tentang Descriptive Text, betul Bu?" Guru menjawab "ya kamu benar, hari ini kita akan belajar tentang Descriptive Text. Ok, ada yang tahu apa arti teks Deskriptif?"

\begin{tabular}{lr}
\multicolumn{3}{r}{ Berdasarkan hasil observasi, } \\
peneliti berpendapat bahwa \\
pembelajaran keterampilan menulis
\end{tabular} dengan pendekatan Genre-Based Approach pada tahap ini lebih baik karena sebelum guru menjelaskan tentang materi teks deskriptif, guru bertanya kepada siswa tentang makna dan memberikan kesempatan kepada siswa untuk belajar. mengeksplorasi pengetahuan mereka. Guru biasanya memberikan latar belakang pengetahuan teks dengan memberikan penjelasan tentang fungsi sosial, ciri kebahasaan, dan pengorganisasian teks. Terkadang, guru menyebutkan beberapa kosakata sulit yang belum pernah ditemukan siswa sebelumnya. Dengan mengajukan pertanyaan di atas, guru mengetahui kemampuan siswanya. Setelah itu guru menjelaskan materi, tetapi jika ada siswa yang tidak mengetahui materi tersebut, guru menjelaskan lebih lanjut sampai siswa mengerti.

b. Memodelkan dan Mendekonstruksi Teks

Pada tahap ini guru meminta siswa untuk melihat di papan tulis karena akan menjelaskan tentang materi dan memberikan contoh teks yang sesuai dengan materi yang akan dibahas. Guru memulai materi dengan jelas. Guru menjelaskan dari pengertian teks deskriptif, tujuan teks deskriptif, struktur generik, fungsi sosial, ciri kebahasaan, dan contoh teks deskriptif yang berjudul "Nikita Willy". Saat ini siswa sedang memperhatikan penjelasan guru. Siswa bertanya kepada guru tentang masalahnya dalam memahami teks deskriptif, guru menjawab pertanyaan siswa dengan jelas.

Setelah itu, guru meminta siswa membaca teks tersebut. Berdasarkan observasi, bagian ini 
digunakan untuk meningkatkan kemampuan membaca siswa dan mereka juga akan mengetahui tata bahasa yang benar. Apabila siswa bingung membaca teks tersebut, maka akan dikoreksi oleh guru. Guru memberikan kata-kata yang sulit dan mendefinisikan artinya dalam bahasa Indonesia. Hal ini tidak selalu dilakukan oleh guru, tetapi dia menafsirkan atau membuat tanya jawab antar siswa. Hal ini dilakukan untuk menghafal kata-kata yang telah diberikan pada pertemuan sebelumnya dan juga meningkatkan kemampuan kosakata siswa.

Guru menunjuk salah satu siswa untuk maju ke depan dan mengidentifikasi struktur umum teks di papan tulis, sedangkan siswa yang lain harus memperhatikan teman-temannya. Berdasarkan teks yang ditulis siswa, guru meminta siswa lainnya untuk menunjukkan struktur umum teks yang digarisbawahi oleh siswa. Siswa yang mampu menjawab dengan benar akan mendapat tambahan nilai dari guru. Guru meminta siswa satu per satu untuk membacakan dengan lantang sebagai berikut:

\section{Malia tolong baca} paragraf pertama! Setelah Malia selesai membaca paragraf pertama, guru tersebut berkata: "Feri tolong lanjutkan membaca paragraf kedua!"

Menurut peneliti sesuai dengan tahapan tersebut karena pada tahap pemodelan ini guru meminta siswa untuk membaca materi yang diberikan. Guru juga meminta siswa untuk maju ke depan dan mengidentifikasi bagian teks deskriptif dengan menggarisbawahi struktur generik. Terkadang guru memberikan contoh bagaimana mengidentifikasi bagian dari teks Deskriptif. Satu paragraf setelah siswa mengulang apa yang guru baca. Kemudian guru meminta siswa untuk menemukan apa yang mereka tidak tahu apa artinya dan menulis di buku mereka dan meminta mereka untuk menemukan kata tersebut dalam kamus. Guru menggunakan power point untuk menjelaskan dan memberi contoh tentang materi teks naratif akan membuat siswa memperhatikan dan tidak bosan. Selain itu dapat meningkatkan kemampuan membaca siswa dan juga mengetahui pengucapan yang benar. Guru dan siswa bekerja sama untuk mengeksplorasi konteks budaya. Itu dibuktikan dengan pernyataan guru:

"Setelah kita membaca teks" Nikita Willy "kita dapat mengetahui apa tujuan dari teks deskriptif itu, struktur generik dan ciri-ciri bahasa dari teks tersebut. Sekarang, saya akan memanggil satu per satu nama siswa untuk menjelaskan apa itu orientasi, kerumitan, resolusi dan reorientasi teks. "'

\section{c. Konstruksi Bersama dari Teks}

Setelah siswa membaca cerita "Nikita Willy" dari power point siswa telah mengenal semua ciri teks deskriptif. Dalam tahapan ini, guru memberi kesempatan kepada siswa untuk membuat kelompok berpasangan untuk membuat teks. Guru membagi kelas menjadi 3 kelompok. Kemudian guru meminta mereka untuk 
membuat naskah tentang "Mendeskripsikan Orang" dengan kata-katanya sendiri berdasarkan motivatornya. Guru memberikan pengumuman bahwa siswa telah bekerja dan harus dipresentasikan di depan kelas.

"Saya meminta Anda membuat kelompok untuk latihan membuat naskah" Mendeskripsikan Orang ". Setelah itu kalian harus berlatih membaca naskah yang telah dibuat sesuai dengan motivator kalian sendiri".

Setelah itu guru memberikan contoh satu kalimat naskah pernyataan Describing People:

"Saya punya motivator. Dia orang nomor satu di Indonesia. Dia Jokowi.".Kemudian guru berlatih membaca satu kalimat kalimat di atas pernyataan Describing People dengan intonasi dan pengucapan yang benar pula. Cara tersebut penting untuk melihat kemampuan membaca dan menulis siswa.

Proses datang ke depan kelas untuk mempresentasikan tugasnya tanpa dipilih oleh guru, namun salah satu kelompok maju dan mulai membaca naskahnya. Menurut peneliti tahapan ini sesuai dengan teori Joint Construction of Text karena dalam kegiatan ini guru melakukan tanya jawab, berdiskusi dan membentuk kelompok kecil untuk membahas materi.

\section{d. Konstruksi Teks Independen}

Pada tahap ini, guru meminta siswa diharapkan dapat bekerja mandiri dengan teks. Guru memberikan beberapa reviewer tentang materi yang berkaitan dengan teks deskriptif bergenre, siswa dapat menjelaskan dan menjawab satu per satu. Dimulai dari pengertian teks deskriptif, fungsi sosial, dan struktur generik dan terakhir ciri-ciri bahasa teks deskriptif. Itu dibuktikan dengan pernyataan dari guru:

"Dari proses belajar mengajar saat ini, kita bisa mengetahui jenis teks teks deskriptif. Sekarang saya ingin mengulas tentang materi dan salah satu siswa harus menjawab apa definisi teks deskriptif, dan siswa lain menjelaskan apa fungsi sosial, struktur generik dan fitur bahasa teks.

Guru menanyakan kepada siswa tentang tugasnya, kegiatan hari ini adalah menyajikan tugas siswa. Mereka harus tampil, menyampaikan tugas mereka. Mereka harus membaca teks skrip mereka dengan jelas berdasarkan motivator mereka yang telah mereka diskusikan dalam kelompok dan meminta kelompok lain untuk mengidentifikasi struktur generik, fitur bahasa, dan menggarisbawahi jawaban di papan tulis. Terbukti guru tersebut mengatakan bahwa:

"Siapa yang akan mempresentasikan naskah teks deskriptif terlebih dahulu? Saya ingin beberapa kelompok untuk hadir, angkat tangan Anda dan sebutkan nama Anda! Jangan lupa untuk kelompok lain untuk mengidentifikasi dan 
menggarisbawahi struktur umum dan fitur bahasa!"

Kemudian salah satu kelompok maju dan mulai menulis naskah mereka di papan tulis. Setelah itu, kelompok lain juga maju satu persatu mempresentasikan teksnya hingga selesai. Saat ini, guru juga sedang mengoreksi kesalahan siswa dalam pelafalan kata.

\section{e. Menautkan Teks Terkait}

Setelah mereview satu persatu siswa, guru membuat variasi review pada penjelasannya, ada penjelasan dan latihan soal. Cara-cara tersebut agar siswa menjadi kreatif, dan mengingat penjelasan guru. Untuk memberikan kesempatan kepada siswa untuk membuat pertanyaan tentang semua materi yang belum dipahami siswa. Poin penting dalam tahap ini adalah memberikan ujian siswa. Setelah materi selesai dilakukan evaluasi dari guru. Evaluasi tersebut adalah tentang mengajar menulis.

Pada tahap ini siswa harus kreatif, dan mengingat penjelasan guru. Guru memberikan tugas kepada siswa untuk membaca teks deskriptif lainnya. Guru meminta siswa untuk menuliskan tentang destinasi indah yang berkaitan dengan teks deskriptif, setelah itu guru akan memanggil siswa satu per satu untuk mengetahui struktur umum dan ciri bahasa teks tersebut di depan kelas. Selain itu, guru juga membuat pertanyaan, mencocokkan materi terkait dan siswa harus menemukan jawaban yang benar terkait teks deskriptif materi. Hal ini dilakukan agar dapat menghafal kata-kata yang telah diberikan pada pertemuan sebelumnya dan juga meningkatkan kemampuan menulis untuk mengingat apa arti dari teks deskriptif.

\section{Masalah yang Dihadapi Guru dalam Mengajar Keterampilan Membaca Menggunakan Pendekatan Genre-Based pada Siswa Kelas X SMA Pendidikan Mulia}

Peneliti akan menjelaskan
pertanyaan tentang rumusan
masalah apa saja masalah yang
dihadapi guru dalam pembelajaran
keterampilan menulis dengan
menggunakan pendekatan Genre-
Based Approach. Setelah dianalisis,
peneliti menemukan bahwa ada
beberapa masalah yang dihadapi
guru seperti:

a. Manajemen Kelas

Dalam hal ini peneliti menemukan masalah yang dihadapi oleh guru ketika peneliti melakukan wawancara dengan guru yaitu guru merasa kesulitan dalam mengelola kelas terutama dari kondisi dan waktu guru merasa siswa membutuhkan usaha yang lebih dalam penguasaan materi tersebut. memahami dan memahami inti materi. Hal tersebut dibuktikan dengan pernyataan guru bahwa:

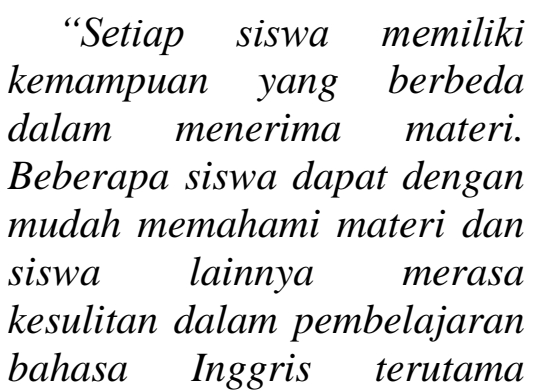


dalam

pembelajaran

keterampilan menulis ".

Ada beberapa alasan mengapa guru merasa kesulitan dalam mengelola kelas karena kondisi siswa tidak sesuai dengan waktu yang diberikan dalam pembelajaran bahasa Inggris karena setiap siswa memiliki kemampuan yang berbeda dalam menerima materi. Ada beberapa siswa yang berpartisipasi aktif dalam kelas menulis, tetapi yang lainnya tidak. Jadi guru mengulang menjelaskan materi agar siswa mengerti sampai siswa mengerti maksud pelajaran.

\section{b. Kurangnya Minat Murid}

Dalam hal ini peneliti menemukan masalah yang dihadapi guru ketika proses pembelajaran menggunakan kelompok untuk membahas tugas masing-masing kelompok. Ketika guru meminta siswa untuk bergabung dengan kelompoknya, kemudian meminta siswa mengerjakan tugasnya dengan kelompoknya, guru tidak dapat memonitor semua kelompok sekaligus hal ini karena guru kurang berminat pada siswa. Hal ini terbukti pada saat peneliti melakukan observasi di kelas peneliti menemukan bahwa guru tidak dapat memantau seluruh siswa, pada saat guru memonitor satu kelompok, kelompok lainnya ribut dan tidak memperhatikan penjelasan guru.

\section{c. Kosa Kata Siswa Lebih Sedikit}

Dalam proses belajar mengajar, peneliti menemukan bahwa siswa mengalami kesulitan dalam menerjemahkan jenis teks terutama pada teks deskriptif. Hal ini dapat dibuktikan ketika siswa yang mencoba menulis teks "Mendeskripsikan Orang" kurang memahami tentang makna teks tersebut. Misalnya dalam menulis alasan mengapa mereka ingin menulis tentang orang tersebut, mereka tahu alasannya tetapi merasa sulit untuk menulis dalam bahasa inggris karena mereka tidak tahu beberapa kata dalam bahasa inggris. Jadi, guru menjadi penerjemah bagi siswa kalimat demi kalimat. Guru juga membuat pembentukan kosakata kata demi kata untuk membantu siswa meningkatkan kosa kata mereka. Dalam pengajaran menulis, kosakata adalah aspek terpenting, tanpa kosakata siswa tidak dapat memahami cara menulis teks, karena mereka tidak tahu bagaimana menjelaskan sesuatu menggunakan bahasa Inggris. Ini akan mengganggu ketika mereka tidak dapat memahami kata asing dan membuat mereka sulit untuk menerjemahkan dan menulis konteks teks.

Menurut peneliti, siswa harus terus menulis teks dan sering menulis teks untuk menambah perbendaharaan kata dan memahami makna dan isi teks.

\section{Solusi Masalah yang Dihadapi Guru dalam Mengajar Keterampilan Menulis Menggunakan Pendekatan Genre-Based di Kelas X SMA Pendidikan Mulia}

Dalam proses pembelajaran menulis teks deskriptif, peneliti menemukan beberapa permasalahan yang berhubungan dengan proses 
belajar mengajar yang dilakukan oleh guru. Guru mencoba solusi untuk memecahkan masalah tersebut sebagai berikut:

\section{a. Guru memberikan Nasehat dan Motivasi}

Solusi pertama dari masalah yang dihadapi guru dalam mengajar keterampilan menulis pada guru merasa kesulitan dalam mengelola kelas. Tidaklah mudah untuk mengajar semua siswa, guru membutuhkan waktu ekstra untuk menguasai materi setelah itu menjelaskan langkah demi langkah hingga siswa memahami materi tersebut. Solusi untuk mengatasi masalah tersebut, guru sebelum mulai mengajarkan materi guru memberikan nasehat dan motivasi agar siswa dapat mencapai materi tersebut. Selain itu guru juga menerapkan metode jigsaw untuk mengatasi masalah tersebut, karena metode jigsaw dapat mengatasi kurangnya aktivitas siswa dan mengajak mereka untuk aktif selama proses pembelajaran.

\section{b. Guru Berbagi Pengalaman Menarik}

Peneliti memiliki solusi kedua dari masalah yang dihadapi guru dalam mengajar keterampilan menulis ketika guru kurang menarik minat siswa. Guru mengalami kesulitan ketika siswa tidak memperhatikan penjelasan guru. Solusi untuk mengatasi masalah tersebut adalah guru berbagi pengalaman yang menarik, dengan berbagi pengalaman yang menarik dapat menumbuhkan minat siswa, sehingga siswa yang merasa kurang minat siswa akan siap mengikuti proses pembelajaran. Setelah itu guru dapat mengajarkan materi dengan jelas mulai dari guru meminta salah satu siswa untuk menulis teks menjadi sumber belajar, siswa maju ke depan kelas hingga mengeceknya. Namun, guru kurang dalam mengawasi semua siswanya,

Selain itu guru berjalan dari satu kelompok ke kelompok lain untuk memantau apa yang dilakukan siswa, terkadang ke samping kanan dan kiri juga melibatkan semua siswa untuk berpartisipasi dalam proses pembelajaran dengan melakukan role play siswa secara bergantian praktek menulis di depan kelas. Selain itu, guru juga harus memberikan motivasi kepada seluruh siswa. Guru menjelaskan materi sampai siswa mengerti. Guru meminta kelompok lain untuk tetap bersuara dan meminta mereka untuk fokus saat proses belajar mengajar.

c. Guru Meminta Siswa Membawa Kamus

Masalah ketiga yang
dihadapi guru dalam mengajar
keterampilan menulis adalah
kurangnya kosakata siswa. Hampir
semua siswa memiliki kosakata
yang kurang meskipun mereka tahu
dan sadar sangat penting untuk
meningkatkan keterampilan
menulis. Umumnya, siswa
kehilangan kosakata ketika guru
mencoba menanyakan teks untuk
mengetahui apa arti dari teks
tersebut. Nah, guru membantu siswa
untuk memberikan makna teks
tersebut, apa tujuannya.

Solusi untuk mengatasi masalah tersebut, guru meminta 
siswa membawa kamus untuk menemukan kata yang sulit untuk meningkatkan kemampuannya. Karena tanpa kamus siswa tidak mencari arti kata dan sayangnya penulis tidak dapat memahami teks tanpa mengetahui apa arti sebagian besar kata tersebut ketika mereka belajar bahasa Inggris atau ketika mereka melakukan latihan. Selain itu, guru juga meminta siswa untuk menuliskan maknanya dalam buku tersebut. Siswa dapat berkonsultasi tentang makna yang mereka temukan di kamus, guru yakin solusi dapat menyelesaikan masalah ini.

Selain itu guru juga memberikan tugas untuk membuat kalimat dengan menggunakan katakatanya sendiri. Siswa langsung terlibat dalam pembahasan katakata sulit tetapi juga dapat menambah kosa kata siswa. Setelah siswa mengetahui apa arti kata tersebut siswa mulai menulis sampai mengetahui dan menemukan tujuan dari teks tersebut, dan struktur generik teks tersebut.

\section{KESIMPULAN}

Dalam penelitian ini, peneliti melakukan penelitian deskriptif untuk mendeskripsikan penerapan Genre-Based Approach dalam pembelajaran keterampilan menulis pada siswa kelas $X$ SMA Pendidikan Mulia. Penelitian ini bertujuan untuk mengetahui penerapan Genre-Based Approach dalam pembelajaran keterampilan menulis, masalah-masalah yang dihadapi guru dalam mengajar keterampilan menulis menggunakan Genre-Based Approach, serta solusi untuk memecahkan masalah yang dihadapi guru dalam pembelajaran keterampilan menulis menggunakan Pendekatan Berbasis Genre.

Berdasarkan data yang diperoleh dari observasi, hasil wawancara, dan juga analisis pencatatan, dapat disimpulkan bahwa ada lima tahapan dalam pembelajaran menulis dengan pendekatan Genre-Based Approach yaitu: Membangun konteks; Memodelkan dan mendekonstruksi teks; Konstruksi teks bersama, Konstruksi teks independen; Menautkan teks terkait. Guru menerapkan langkah-langkah dalam Pendekatan Berbasis Genre dengan baik, guru mengikuti semua aturan dalam siklus belajar mengajar Pendekatan Berbasis Genre. Semua tahapan tersebut guru melaksanakan tahapan dalam proses pembelajaran keterampilan menulis dan dapat menyeimbangkan antara masalah yang dihadapi guru dalam mengajar keterampilan menulis dengan menggunakan Pendekatan Berbasis Genre. Karena dalam menggunakan tahapan tersebut,

Terdapat beberapa kendala yang dihadapi guru dalam pembelajaran keterampilan menulis dengan pendekatan Genre-Based Approach antara lain: guru merasa siswa membutuhkan waktu ekstra untuk menguasai materi. Karena tidak semua siswa memiliki kemampuan yang sama dalam menerima materi, maka guru juga membutuhkan lebih banyak waktu untuk mengelola kelas untuk menjelaskan materi hingga siswanya memahami materi. Guru kurang diminati muridnya, karena ketika guru mengawasi satu kelompok, kelompok yang lain ribut 
dan tidak memperhatikan penjelasan guru. Guru juga mengalami kendala ketika siswa kurang kosakata, hal ini dikarenakan tidak semua siswa memiliki kemampuan yang sama dalam menerima materi, ada siswa yang mengerti tetapi ada juga siswa yang tidak mengerti tentang kosakata.

Solusi dari permasalahan guru dalam pembelajaran keterampilan menulis dengan pendekatan GenreBased Approach adalah: guru perlu mengelola kelas untuk menguasai materi untuk menyelesaikan masalah tersebut guru sebelum mulai mengajar materi guru memberikan nasehat dan motivasi, sehingga siswa dapat mencapai tujuan. bahan. Guru harus menjelaskan langkah demi langkah sampai siswa memahami materi. Guru kurang memiliki minat siswa, untuk mengatasi masalah tersebut guru berbagi pengalaman yang menarik, dengan berbagi pengalaman yang menarik dapat membangun minat siswa, sehingga siswa yang merasa kurang minat siswanya akan siap mengikuti proses pembelajaran. Para siswa memiliki kosakata yang lebih sedikit, untuk mengatasi masalah ini, para guru menginstruksikan mereka untuk membawa kamus saat mereka belajar bahasa Inggris atau saat mereka melakukan latihan.

\section{SARAN}

Setelah menganalisis dan membuat kesimpulan tentang penelitian tersebut, peneliti memberikan beberapa saran yang berguna bagi guru, institusi dan lainlain serta bagi siswa.

\section{Untuk Guru}

Guru hendaknya memiliki kreativitas dalam mendidik siswa agar tidak merasa bosan dalam proses pembelajaran membaca di kelas. Mereka harus menggunakan langkah dalam Pendekatan Berbasis Genre secara tepat dan teratur. Atur waktu dengan cermat agar siswa mendapatkan proporsi materi yang tepat.

2. Untuk Institusi

Memberi waktu ekstra bagi guru untuk mengajar bahasa Inggris, bisa di luar sekolah.

3. Untuk para Siswa

Para siswa harus menemukan cara mereka tertarik pada bahasa Inggris di luar sekolah. Mereka harus mengikuti instruksi dari guru, ketika mereka diperintahkan untuk melakukan sesuatu, mereka harus melakukannya dengan baik.

\section{DAFTAR PUSTAKA}

Brown, H. Douglas. (2000). Principles of Language Teaching and Learning (4th Ed.).New York: Pearson Education.

Brown, H. Douglas. (2001).

Teaching by Principles: An Interactive Approach to Language Pedagogy (2nd Ed.). New York: Pearson Education

Creswell, John W. (2014). Research Design Qualitative, Quantitative and Mixed Methods Approaches. United Kingdom: SAGE Publications Ltd.

Dirgeyasa, Wy. I. (2015). What and How to Assess a Genre-Based Writing. Proceeding of 4th 
Nurvita Sari Musdiani Silalahi ${ }^{1}$, Silvy P. Maharani ${ }^{2}$, Afanin Nabila ${ }^{3}$

Penerapan Pendekatan Berbasis Genre Dalam Pengajaran Menulis Teks Pada

Siswa Kelas X SMA Swasta Mulia

International Conference on

Language Education. 2015.

State University of Makasar

South Sulewesi Indonesia.

Fauziati, Endang. 2009. Introduction to Methods and Approaches in Second or Foreign Language Teaching. Surakarta: Era Pustaka Utama.

Heigham, Juanita and Robert A. Croker. 2009. Qualitative Research in Applied Linguistics A Practical Introduction. New York: Palgrave Macmillan.

Lerdpreedakorn, N. (2009). Genrebased Approach to Teaching Academic Writing. In A.

M. Stoke (Ed.), JALT 2008 Conference Proceedings: Tokyo: JALT. Moleong Lexy J. 2004. Metodologi Penelitian Kualitatif. Bandung: Remaja Rosdakary

Nunan. 2003. Practical English Language Teaching. Cambridge: Cambridge University Press.

Stoke, J. (2006). How to do Media and Cultural Studies diterjemahkan oleh Santri Indah Astuti (Panduan untuk Melaksanakan Penelitian dalam Kajian Media dan Budaya, Yogyakarta: PT. Benteng Pustaka. 